\author{
Anne Kluger \\ ORCID 0000-0002-9781-788X \\ Westfälische Wilhelms-Universität Münster, Institute of History, \\ Department of Eastern European History (Münster, Germany) \\ anne.kluger@uni-muenster.de
}

\title{
Between pottery and politics? "Slavic archaeology" in communist Poland and East Germany and its interrelations with politics and ideology. A biographical-comparative approach
}

\begin{abstract}
Despite the previous overview studies on Polish and East German archaeology and historiography after 1945, further analyses of the relationship between science and politics as well as of the inner-disciplinary processes and discourses in the "Cold War" period are still needed. This applies in particular to the research field of "Slavic archaeology", the archaeological and historiographical research on the "Slavs" in prehistorical and early medieval times.
\end{abstract}

\begin{tabular}{|c|c|c|c|c|c|}
\hline \multicolumn{2}{|c|}{$\begin{array}{l}\text { PUBLICATION } \\
\text { INFO }\end{array}$} & Pistoriae & $\begin{array}{r}\text { e-ISSN 2543-702X } \\
\text { ISSN 2451-3202 }\end{array}$ & 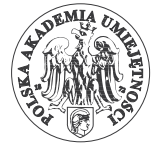 & $\begin{array}{c}2 \\
\text { DIAMOND } \\
\text { OPEN ACCESS }\end{array}$ \\
\hline \multicolumn{6}{|c|}{$\begin{array}{l}\text { CITATION } \\
\text { Kluger, Anne 2020: Between pottery and politics? "Slavic archaeology" in communist Poland and East } \\
\text { Germany and its interrelations with politics and ideology. A biographical-comparative approach. Studia } \\
\text { Historiae Scientiarum 19, pp. 287-326. DOI: } 10.4467 / 2543702 X S H S .20 .010 .12566 \text {. }\end{array}$} \\
\hline \multicolumn{3}{|c|}{$\begin{array}{l}\text { RECEIVED: } 11.09 .2019 \\
\text { ACCEPTED: } 22.08 .2020 \\
\text { PUBLISHED ONLINE: } 30.09 .2020\end{array}$} & $\begin{array}{l}\text { ARCHIVE } \\
\text { POLICY } \\
\text { Green SHERPA/ } \\
\text { RoMEO Colour }\end{array}$ & 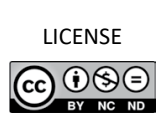 & $\begin{array}{l}\text { Crossref } \\
\text { Similarity Check } \\
\text { Ponered by ithentioate }\end{array}$ \\
\hline www & \multicolumn{5}{|c|}{ https://ois.ejournals.eu/SHS/; http://pau.krakow.pl/Studia-Historiae-Scientiarum/archiwum } \\
\hline
\end{tabular}


With regard to recent demands for an extended and more dynamic understanding of science and new methodological approaches in the history of science (and of archaeology as well), this paper focuses on two leading figures of "Slavic archaeology", Witold Hensel (PPR) and Joachim Herrmann (GDR), as case studies to provide more insights into this discipline.

Analysing the course of Hensel's and Herrmann's careers and of their way to the "Slavs" as one of their main research interests, their administrative functions as institutional directors and the central narratives of their publications on the early "Slavs", provides the opportunity to profoundly dissect the interrelations between scholarly work, politics, and ideology in this field of research.

The comparative approach also makes it possible to identify parallel tendencies in Eastern German and Polish "Slavic archaeology" as well as specific national conditions and developments.

On the example of Hensel and Herrmann, it becomes clear that the implemented biographical-comparative perspective is fruitful and can be used for further research in the history of science.

Keywords: Slavic archaeology, prehistory, Witold Hensel, Joachim Herrmann, East Germany, Poland, communism, history of science, history of archaeology, biography

\title{
Między ceramiką a polityką?
} „Archeologia słowiańska” w komunistycznej Polsce i Niemczech Wschodnich

\section{i jej związki z polityką i ideologią. Podejście biograficzno-porównawcze}

\begin{abstract}
Abstrakt
Pomimo dotychczasowych badań przeglądowych dotyczących archeologii i historiografii Polski i NRD po 1945 r., nadal potrzebne są dalsze analizy związków między nauką a polityka, a także wewnętrznych procesów dyscyplinarnych i dyskursów
\end{abstract}


w okresie ,zimnej wojny”. Dotyczy to w szczególności badań „archeologii słowiańskiej”, badań archeologicznych i historiograficznych „Słowian” w czasach prehistorycznych i wczesnego średniowiecza.

W związku z ostatnimi wymaganiami szerszego i bardziej dynamicznego rozumienia nauki oraz stawania nowych podejść metodologicznych w historii nauki (a także archeologii), niniejszy artykuł koncentruje się na dwóch wiodących postaciach „archeologii słowiańskiej”, Witoldzie Henselu (PPR) i Joachimie Herrmannie (NRD), jako studiach przypadków, aby zapewnić większy wgląd w tę dyscyplinę.

Analiza przebiegu kariery Hensela i Herrmanna oraz ich dróg wiodących do „Słowian” jako jednego z głównych zainteresowań badawczych, ich funkcji administracyjnych jako dyrektorów instytucjonalnych oraz głównych narracji ich publikacji naukowych o wczesnych „Słowianach”, umożliwia dogłębnie przeanalizować zależności między pracą naukową, polityką i ideologia w tej dziedzinie badań.

Podejście porównawcze pozwala również na identyfikację równoległych tendencji we wschodnioniemieckiej i polskiej „archeologii słowiańskiej”, a także na specyficzne społeczne uwarunkowania i rozwój sytuacji w tych krajach.

$\mathrm{Na}$ przykładzie Hensela i Herrmanna staje się jasne, że wdrożona perspektywa biograficzno-porównawcza jest owocna i może być wykorzystana do dalszych badań w historii nauki.

Słowa kluczowe: archeologia stowiańska, prehistoria, Witold Hensel, Joachim Herrmann, NRD, Polska, komunizm, bistoria nauki, historia archeologii, biografia

\section{Introduction}

It almost sounds like an advertising slogan when the archaeologist and historian Marc-Antoine Kaeser points to the special value of biographies for the history of science: According to him, looking at the case examples of single scholars (instead of analysing the history of a discipline or an area of research from a broader perspective) promises "unique insights into the concrete realities of science in the making"'. Kaeser's statement actually corresponds with a more general

\footnotetext{
1 Kaeser 2008, p. 18.
} 
development in the history of science: As a result of theoretical discussions, paradigm shifts and different "practical" experiments, researchers increasingly aim to avoid telling only the linear success story of scientific results while ignoring how they have been found. ${ }^{2}$ Instead, the focus is more and more on the generation of scientific knowledge as a "social process" ("als ein $[\ldots]$ soziale $[\mathrm{r}]$ Proze $\beta^{\text {" }}$ ). Therefore, historians of science look closely at "the political and social parameters of scholarly and intellectual developments" 4 and extend their perspective on the complexities and dynamics of the academic field. ${ }^{5}$ The tendency is to move away from creating "a unifying grand narrative of inexorable progress, across time, towards truth" and to provide "more critical and contextual histories"'. In this context, as also shown by Kaeser's comment cited above, researchers come back to biographical approaches.

Due to controversial debates and fierce criticism (for example Bourdieu's famous reflections on the "biographical illusion") ${ }^{8}$ biographies have experienced various adjustments over the past decades and more attention is now being paid to the (until then rather deficient) theoretical and methodological foundation of the genre. ${ }^{9}$ This is also reflected on the level of actual biography writing. Although there are still many examples of "classical" scientific biographies about prominent scholars whose life stories and academic careers are presented in chronological order as cohesive, somehow "goal-oriented" and meaningful sequences of events, ${ }^{10}$ more and more alternative approaches can now be observed and the genre has gained new reputation in the academic sphere in general. Biographies meanwhile appear in "many forms and

2 Eckel 2008, p. 90; Kaeser 2008, pp. 9, 17; Strupp 2008, p. 112.

3 Szöllösi-Janze 2000, p. 20.

${ }^{4}$ Lässig 2008, p. 15.

5 Eckel 2008, pp. 85-86; Kaeser 2008, p. 12; Lässig 2008, p. 15; Nordbladh; Schlanger 2008, p. 3; Szöllösi-Janze 2000, pp. 20-22, 29-30; Veit 2011, pp. 34, 37-38.

${ }^{6}$ Nordbladh; Schlanger 2008, p. 1.

7 Nordbladh; Schlanger 2008, p. 1.

${ }^{8}$ Originally Bourdieu 1986, pp. 69-72.

9 Berghahn 2008, p. 239; Harders 2014, p. 49; Kershaw 2008, pp. 27-32; Lässig 2008, pp. 3-4; Loriga 2014, p. 89; Nasaw 2009, pp. 576-577; Pyta 2009, p. 332; Strupp 2008, p. 115; Szöllösi-Janze 2000, pp. 17, 20.

${ }^{10}$ Harders 2014, p. 54; Lässig 2008, p. 6; Renders 2014, p. 132; Schweiger 2009, p. 34. 
sizes"11, as for example, collective and prosopographical analyses enjoy increasing popularity. ${ }^{12}$

The potential of such new types of biographies has also been rediscovered in the history of archaeology in recent years along with its development from an eccentric hobby, which often served legitimising, commemorating and self-assuring purposes, to a recognized field of research. ${ }^{13}$ However, according to Marc-Antoine Kaeser and Ulrich Veit for instance, the history of archaeology still needs to catch up theoretically and methodologically with other disciplines that are more experienced and/or more advanced in critically examining their own past (like historiography for example). They determine avoiding "internalist" perspectives (which means: analysing the past of the discipline "regardless of the scientific context in which it developed"14) as well as "presentism" (that is: the search for answers in the past to contemporary questions) as the main challenge for the history of archaeology. ${ }^{15}$ Especially biographical approaches with a close connection to primary sources are considered a helpful tool to overcome these difficulties. ${ }^{16}$

\section{The thematic focus: East German and Polish "Slavic archaeology" and its protagonists Joachim Herrmann and Witold Hensel}

In this paper, in order to evaluate the actual "usability" of the assumptions elaborated above, they will be applied to a concrete example. I will therefore focus on an object of research from the history of archaeology and prehistory (in fact located at the interface between archaeology and history) that definitely deserves more attention than it has received so far: the "Slavic Archaeology" in the so-called Eastern bloc and its protagonists. Although several overview studies on prehistorical and

${ }^{11}$ De Haan; Renders 2014, p. 5.

${ }^{12}$ Harders; Lipphardt 2006, p. 81.

13 Kaeser 2006, p. 307; 2008, p. 9; Nordbladh; Schlanger 2008, p. 1; Veit 2011, pp. 34-36, 40, 49-50. See Hoppe; Quadflieg 2010, p. 6 (on the same phenomenon in history).

${ }_{14}$ Kaeser 2008, p. 15.

15 Kaeser 2006, pp. 307, 310; 2008, pp. 11, 18; Veit 2011, pp. 35, 37-38, 51.

${ }_{16}$ Kaeser 2008, p. 18. 
medieval history and archaeology in the Socialist countries on the one hand, and on the development of the image of the "Slavs" 17 across time on the other hand have already been published, there is still need for further research on these topics and for bringing together the different angles of vision in particular. Therefore, in this paper, two leading figures of "Slavic archaeology" from communist Poland and East Germany will serve as case studies to dissect the interrelations between scholarly work, politics, and ideology in the discipline: Witold Hensel from the PPR, ${ }^{18}$ who was the director of the archaeological and prehistorical institute at the Polish Academy of Sciences ("Instytut Historii Kultury Materialnej", IHKM PAN), and Joachim Herrmann from the GDR, who also held an influential position as head of the equivalent institution at the East German Academy of Sciences ("Zentralinstitut für Alte Geschichte und Archäologie", ZIAGA AdW).

\subsection{The Research Question}

Based on these examples, I intend to demonstrate that especially a comparative biographical study can help to draw conclusions on "science in the making" and to decipher if, or respectively to what extent we can assume a certain level of (forced or chosen) political and ideological "penetration" of "Slavic archaeology" in the GDR and the PPR. The term "penetration" takes up the current theoretical reflections on the connections between the scientific and the political sphere. ${ }^{19}$

17 The term „Slavs” (as well as “Germanic”, etc.) and related words are used in quotation marks in this paper. This is in no way meant as a devaluation or disregard for the historical and cultural significance of entities and developments that are assigned to the "Slavs" in current and past research. It rather serves to reflect the problem of simplifying applications of ethnic-linguistic collective terms to prehistoric units and archaeologically defined (material) cultures, as this issue is a central subject of today's theoretical discussion in archaeology (and also beyond disciplinary boundaries). For further information and different arguments, see, for example, Brather 2009; Curta 2001a; Curta 2001b; Gąssowski 2003; Mühle 2020; Pohl 1999; Urbańczyk 2003. For an overview over the current state of discussion, see Hardt 2015, pp. 16-24.

18 The official state name "Polska Rzeczpospolita Ludowa"/ "Polish People's Republic" (PRL/PPR) was only established with the change of constitution in 1952. Nevertheless, as an analytical term, "PRL/PPR" is also applied to the time of communist rule in Poland in total - and is used here in that sense as well.

${ }_{19}$ In addition to the remarks above see Ash 2002, pp. 32-51; Troebst 2013, pp. 15-36; Wolfrum 1999, pp. 13-38. 
It is used to avoid a one-dimensional perspective on the role of scientists and to widen the scale instead, as it gets the scientists out of the "ivory tower" and examines various forms and phenomena of relations between academia, society, and politics. This creates a more differentiated picture of scholars between the extreme poles of either passive victims of exterior instrumentalization or eager henchmen to the political authorities. ${ }^{20}$ Of course, it must be taken into consideration that in non-democratic systems (as in the regimes in East Germany and Poland after 1945) the interrelations between the archaeological and the political sphere develop under specific conditions. ${ }^{21}$ Nevertheless, I intend to avoid "exoticizing" these entanglements as something exclusively occurring under authoritarian circumstances: The way how politics, ideology, and scholarly work were interwoven in East German and Polish "Slavic archaeology" can be worked out all the more clearly, if the question whether history and archaeology can in principle be (or rather not be) "objective" and detached from non-scientific factors is comprehensively considered. ${ }^{22}$ The approach via two case studies contributes even better to taking a close look at the respective conditions for research that we have to keep in mind analyzing "Slavic archaeology" in communist East Germany and Poland, and, by that, prevents generalizations. By the example of Hensel and Herrmann, I therefore aim to answer the question to what extent they endeavoured to assert certain spaces for action and/or actively (out of conviction or pragmatism) contributed to political and ideological goals.

In this respect, the paper also follows a microhistorical approach to some degree, as in microhistory, the analytical focus is narrowed to particular phenomena from the past (which can be problems, areas, events/ situations, groups, single actors...) in such a manner that very specific objects of research are examined, and limited, small-scale research questions can be pursued. ${ }^{23}$ Like microhistorians, who always aim to then

${ }^{20}$ Ash 2002, p. 33.

${ }^{21}$ Gediga 2004, pp. 215-216; Neustupný 2004, pp. 225, 228.

22 Neustupný 2004, p. 233, notes pointedly that archaeologists (and scientists in general) do not exist "in a vacuum" but are "influenced and determined by their non-archaeological environment" - may it be the reliance on financial funding or the need for permission to travel abroad to attend scientific conferences for example.

${ }^{23}$ De Haan, Renders 2014, p. 5; Frijhoff 2008, p. 215; Peltonen 2014, pp. 105-107, 
"draw far wider generalizations" 24 in respect of larger "macro" contexts, the "bigger pictures", so to say, and to reconstruct the specific historical conditions of a certain time and space based on their "micro studies", I also intend to extensively include contextual factors (the "macro level"), like the political and social circumstances in Poland and East Germany, the science policy of the Communist regimes, the structure and functioning of the research landscapes in both countries etc., into my analysis as well as to derive new results concerning their reciprocal relationship with my two case examples (as the "micro level").

\subsection{The sources and the structure of the analysis}

As Hensel and Herrmann have not yet been main subjects of biographical monographies or papers, ${ }^{25}$ it is necessary to mostly rely on primary sources (which can of course be complemented and contextualized by research literature about archaeology, history and the image of the "Slavs" in the course of time). The central sources concerning Hensel and Herrmann that are available are biographical, personal administrative, and "general" administrative documents, which are stored mainly in the archives of the institutes that Hensel and Herrmann led, as well as their scientific publications on the early "Slavs".

With regard to the approach of this paper, I aim to apply an alternative way to present my case examples, breaking up the classical biographical pattern: Of course, Hensel's and Herrmann's curricula vitae will also be considered here, but instead of re-narrating their life stories from birth to death, the key moments and phases in their lives will only be addressed in relation to their relevance for the research question.

110-112; Renders 2014, p. 138. Therefore, Kaeser 2006, p. 309, describes the relationship between microhistory and "general history" as similar to the connection of cell biology and general scientific morphology.

${ }^{24}$ Levi 1994, p. 98.

25 Burda 2004, p. 332, points out that there has been a "revival of the discussion about the post-war history” („ożywienie[...] dyskusji nad powojenna historia naszej nauki") of archaeology in Poland, which is still continuing and demands further research. Leube 2010a, p. 150, explicitly states that "an objective picture of the person Herrmann, his scientific achievements and his political attitude, which takes due account of the circumstances of the time, is still outstanding" "Eine objektive und den Zeitumständen gerecht werdende Darstellung der Person Joachim Herrmanns, der wissenschaftlichen Leistungen und seiner politischen Haltungen steht noch aus.”). 
That is why this paper at the same time does not provide detailed descriptions of every part of their lives (for example their family background and socialisation, their side-line jobs and activities in addition to their first professional experiences, etc.). Although it is certainly desirable to obtain more information about these "unknown" biographical parts in general, a detailed analysis of these aspects cannot and should not be part of this study as it focuses on the connection between Hensel's and Herrmann's biographies and the development and specifics of "Slavic archaeology". ${ }^{26}$ Therefore, Hensel and Herrmann are to serve as "prisms" 27 through which the specific conditions of prehistorical and early medieval archaeology and history, and especially of "Slavic archaeology", in the GDR and the PPR can be described. The focus is on examining how Hensel and Herrmann started their careers and how their research interest in the early "Slavs" can be explained (3.1.), on pointing out how they got into the positions of institute leaders and how their potential as well as actual exertions of influence on the organization of science can be described (3.2.), and on analyzing the central lines of argumentations in their scientific publications on the early "Slavs" with regard to possible ideological and political "penetrations" (3.3.). Following this structure, it is explicitly not my intention to evaluate Hensel's and Herrmann's behaviour in terms of moral categories.

\section{Analysis}

\subsection{Old structures or new findings? Hensel's and Herrmann's academical careers and their way to the "Slavs"}

Witold Hensel came from what in communist terminology would be called a "bourgeois" family. He was born in 1917 in Poznań but grew up and went to school in Gniezno where his father, a civil engineer, had first worked as a building officer for the municipality, before in the 1920s,

${ }^{26}$ The author is aware of the existing need for more research into these parts of Hensel's and Herrmann's biographies and has already taken important steps in the search for additional sources and in the evaluation of those (few) already known to the scientific community and those newly discovered by her. As this process still needs to be continued and such aspects do not concern the subject of this paper, the results will be left out here and explained in another context as part of a detailed interpretation.

27 The term "prism" for biographical studies is also used by Kershaw 2008, pp. 35, 38, and Strupp 2008, p. 107. 
he functioned as mayor and vice city president and held other positions in the city administration. ${ }^{28}$ From 1934 to 1938, Witold Hensel studied prehistory, ethnography (with ethnology), anthropology and history in Poznań, where Józef Kostrzewski, Kazimierz Tymieniecki, and other politically engaged scholars belonged to his teachers. ${ }^{29}$ At this time, Poznan was the centre of archaeological and historical research connected with the so-called "myśl zachodnia" ("Western thought"). The resident researchers were highly involved in confrontations with German historiography and archaeology about the prehistorical and medieval "Slavic" or "Germanic"/"German" past of the border areas and both sides used archaeological and historical interpretations as political arguments for territorial claims. ${ }^{30}$ It was also under the leadership of Kostrzewski, that Hensel could gain his first experience in archaeological field work (i. a. in Biskupin, Gniezno, etc.). ${ }^{31}$ After finishing his studies, Hensel continued his practical work in Poznań, where he mainly dealt with questions concerning the Piasts (the first Polish ruling dynasty) and the origins of the first medieval Polish state. From this point at the latest, he therefore became actively involved in the quarrels between Polish and German archaeologists, which intensified in the context of the rise of National Socialism in Germany. ${ }^{32}$

28 Archiwum IAE 1391/OS-26, Życiorys' Sylwetki naukowe członków PAN, p. 105, Urbańczyk 2008, p. 147.

29 Archiwum IAE 1391/OS-26, Sylwetki naukowe członków PAN, p. 105; Młynarska-Kaletynowa 2017, p. 11; Urbańczyk 2008, p. 147.

30 See, for example, Stobiecki 2007, p. 108. The concept of the "myśl zachodnia" dates back even further and contains various configurations. With regard to the interwar period, it can be defined as the idea of legitimizing - and sometimes even extending - the Polish western border of 1919 against German revanchist tendencies by referring to the prehistoric and medieval "Slavic" and "Polish" roots of the western Polish borderlands. For further information on the "Westforschung" etc., see i.a. Briesewitz 2014; Hackmann, Jaworski, Piskorski 2002; Krzoska 2001. For further information on the situation of Polish archaeology in the interwar period, see for example Kozłowski 2007, pp. 273-274; Lech 2009, p. 195-196.

31 Archiwum IAE, 1391/OS-26, Życiorys; Sylwetki naukowe członków PAN, p. 105. Hensel's relationship with Kostrzewski is also commented by Kostrzewski in his autobiography in 1970 as well as by Hensel, for example in a retrospective interview in 2008 and therefore offers potential for further research, see Urbanczyk 2008, pp. 154-155; Kostrzewski 1970, p. 146.

32 Archiwum IAE, 1391/OS-26, Sylwetki naukowe członków PAN, p. 105. 
Hensel's scientific career was then interrupted by the war and the occupation of Poland by Nazi Germany. From 1944, he could finally continue his scientific career by finishing his doctoral thesis and teaching in Lublin, which had already been "liberated" by the Red Army. ${ }^{33}$ It is also documented that immediately after the war, Hensel temporarily worked for the department of culture and art of the "Polski Komitet Wyzwolenia Narodowego" ("Polish Committee of National Liberation", PKWN), which was established by the communists in 1944 as the provisional government. In this function, he was responsible for the protection of historical monuments. ${ }^{34}$ Further important steps of his career after the war took place in Poznan, ${ }^{35}$ where he worked for the "Instytut Zachodni" ("West Institute"), founded in 1944/45, and finished his habilitation about the early settlements in the Wielkopolska area. So, in Poznań, Hensel continued concentrating on "Slavic" and "Polish" topics such as the Piast Poland, the history of Wielkopolska and the origins of the "Slavs". ${ }^{36}$ Therefore, his research on the prehistorical and medieval "Slavs" is in line with the tradition of the interwar period, because Hensel also aimed to prove the long Polish tradition of the "recovered territories" (the new Polish territories in the West, which had belonged to the German state territory before the war) and, thus, to legitimize the new western border of Poland. These research interests also matched the new political conditions, especially in the post-war period and the early years of socialism in Poland, when the instability of the new border in the West was one of the greatest fears of Polish society. The communist rulers tried to appease and, at the same time, to instrumentalize these concerns against their international and national political opponents to gain the people's support. In this period, the use of national or even nationalist rhetoric served as one of the main strategies of the communist forces in Poland. They also relied on these ideas

33 Kośnik 2007, pp. 219-221; Urbanczyk 2008, pp. 151-152.

34 Archiwum IAE, 1391/OS-26, Sylwetki naukowe członków PAN, p. 106; Kośnik 2007, pp. 221-225. For further information on Hensel's accompanying activities in Lublin see Kośnik 2007, pp. 220-225.

35 In an interview with Joanna Kośnik, Hensel explained the difficulties during his short "stopover" in Warsaw that motivated him to continue his career in Poznań, see Kośnik 2007, p. 225.

36 Archiwum IAE, 1391/OS-26, Sylwetki naukowe członków PAN, p. 106; Lech 1997/1998, p. 63; Urbanczyk 2008, p. 155. 
to divert attention from the loss of territory in the east and to deny their huge dependence on the Soviet Union. ${ }^{37}$ As shown by previous research, the interests of the traditional "research on the West" (Polish "Westforschung" in German, as the equivalent to the German "Ostforschung" / "research on the East") and the new rulers coincided. Due to this as well as to the communists' focus on other priorities, the disciplines archaeology and history were still dominated by "bourgeois" representatives from the interwar period and their pupils, especially when it came to the history of the "Polish West". ${ }^{38}$ Of course, this was also a consequence of the general lack of scientific personnel resulting from the extinction of Polish intellectuals during the Nazi occupation. ${ }^{39}$ Therefore, scientists and politicians both aimed to assert their convictions as well as to use the correlation of interests pragmatically to achieve their goals. ${ }^{40}$ Hensel's research also has to be seen in this context.

Comparing Hensel's early career and his way to the "Slavs" to Joachim Herrmann, some similarities as well as significant differences can be observed. Here, biographical aspects can fruitfully be linked with the analysis of national varieties and transnational parallels of the Polish and East German "Slavic archaeologies" in particular and the archaeological and historical research landscapes and their interrelations with politics and ideology in these countries in general, which shows the added value of the comparative biographical approach.

Joachim Herrmann was born in 1932 and grew up in the village Lübnitz (in the district of [Bad] Belzig) as the son of a farmer and miller. ${ }^{41}$ Thus, Herrmann was significantly younger than Hensel and therefore,

${ }^{37}$ For an in-depth analysis on this strategy, see for example, Behrends 2009; Górny 2011; Wawrzyniak 2006; Zaremba 2011.

38 Stobiecki 2007, pp. 107-108. For a deeper analysis of the different conflicting tendencies in Polish archaeology after 1945 (from supporters of a continuation of the prewar research traditions to sympathizers with communist theoretical paradigms), see for example Stobiecki 2007, pp. 106-109. For further information on the interrelations of research and politics concerning the "recovered territories", see Grzechnik 2017, pp. 669, 672; Lech 2009, p. 193-194; Piotrowska 1997/1998, p. 271; Szczerba 2018, p. 248-249; Wawrzyniak 2006, pp. 298-319.

39 Bursche, Taylor 1991, p. 588; Guth 2015, pp. 315-317; Kozłowski 2007, p. 274; Stobiecki 2007, p. 106; Szczerba 2018, p. 247.

40 Stobiecki 2007, p. 110; Szczerba 2018, p. 248-249.

${ }^{41}$ Brather 2010, p. 201; Donat, Gramsch, Klengel 2012, p. 8; Leube 2010a, p. 144. 
according to the model of Werner Coblenz, did not belong to the "first" but to the "second" generation of scientists of the Eastern bloc. This generational difference does not only refer to his age but mainly to the fact that, in contrast to Hensel, Herrmann received his academic education under the new political system after the war. ${ }^{42}$ These circumstances included, for example, the first two so-called Higher Education Reforms in 1945 and 1951/52. The reforms did not only obligate all students to basic lessons in Marxism-Leninism and took a further step towards centralising the academic landscape and the course of studies but also aimed to enable more workers' and peasants' children to attend university. ${ }^{43}$ As a result, the higher education system in East Germany differed from the Polish one, where - as research has already pointed out - representatives of the middle and upper class (of the "bourgeoisie" in communist terms) dominated the universities and the research institutions. ${ }^{44}$ To a certain extent, the different family backgrounds and courses of education of the two biographical examples reflect this national difference - Hensel's "bourgeois" family roots on the one hand and Herrmann's peasant origins on the other hand.

Due to the reorganisations that followed the East German reforms, the "Department for Early History and Prehistory" was founded at the Humboldt University in Berlin in 1953 and was finally transformed into the "Institute for Early History and Prehistory" in $1954 .{ }^{45}$ In response to that, Joachim Herrmann, who had begun his studies in 1951, changed his subject from history to prehistory in $1953 .{ }^{46}$ Although Herrmann's university teachers, like Karl-Heinz Otto, Paul Grimm and Gerhard Mildenberger, were members of Coblenz's "first generation", they had turned away from the previous research principles (with regard to the new political and ideological circumstances after 1945), which - in some cases - also meant turning away from previous political

${ }^{42}$ Coblenz 2002, p. 312.

${ }^{43}$ Leube 2010b, p. 127.

${ }^{44}$ Ash 1995, p. 912; Guth 2015, p. 315; Kossack 1999, pp. 83-84, 90.

${ }^{45}$ Leube 2010b, p. 127.

46 Archiv der BBAW: VA-PA, Prof. Herrmann, Joachim, Bewerbung Herrmanns um außerplanmäßige wissenschaftliche Aspirantur vom 4.8.1957; Leube 2010a, p. 144. "Since the systematisation of Joachim Herrmann's papers in the archive is not yet entirely finished at the completion time of this paper, it is possible that details concerning the archival reference numbers may still change." 
convictions. ${ }^{47}$ In contrast to Poland, in the East German case, it was unthinkable to take up the research traditions from the interwar period at least not in a recognizable way. The rejection of the old so-called "fascist" or "imperialist" research was instead one of the proclaimed cornerstones of the East German scientific landscape, just as the radical break with the past served as one of the political founding myths of the GDR. ${ }^{48}$

When Herrmann graduated in 1955 with a study about the economic development in early Iron Age Denmark, he used the Marxist term "Produktivkräfte" ("productive forces") in the title of his diploma thesis. ${ }^{49}$ This indicates the required application of Marxist-Leninist methodology and terminology to pre-modern periods, which Herrmann willingly implemented, as will be shown later. After graduation, Herrmann first worked as a freelance excavation supervisor, before he was finally given a permanent employment at the "Institute of Early History and Prehistory" at the "German Academy of Sciences at Berlin" (as the academy of the GDR was called until 1972). It was in the context of his field work in the area of Berlin and Potsdam that Herrmann more and more focused on the scientific examination of the early "Slavs". His dissertation and habilitation theses (1958 and 1965, published in 1968) were based on the interpretation of his excavational findings and, therefore, dealt with topics related to "Slavic archaeology". ${ }^{50}$

Therefore, Hensel's and Herrmann's concentration on the "Slavs" also arose, among other factors, from their academical education and from the tasks they were given at the early stage of their careers. It will be analyzed later how Hensel and Herrmann themselves described their motivation to do research on "Slavic" topics, and how far these arguments contained aspects of ideological and/or political "penetration" (3.3.).

47 Brather 2010, p. 211. For further information on these persons, s. the respective biographical articles in Leube 2010b. Another example for a pre-war researcher who continued his career in the GDR institutional research landscape is Wilhelm Unverzagt. For an in-depth analysis of his career, see Brather 2001b.

${ }^{48}$ Coblenz 2002, pp. 310-311; Guth 2015, pp. 324-326.

49 Archiv der BBAW: VA-PA, Prof. Herrmann, Joachim, Bewerbung Herrmanns um außerplanmäßige wissenschaftliche Aspirantur vom 4.8.1957.

50 Archiv der BBAW: VA-PA, Prof. Herrmann, Joachim, Bewerbung Herrmanns um außerplanmäßige wissenschaftliche Aspirantur vom 4.8.1957; Brather, Nachruf, pp. 211-212; Leube 2010a, p. 145. 
At this point, it can be stated that the comparison of Hensel's and Herrmann's biographies illustrates that, although both research landscapes in part faced similar challenges, the turn towards "Slavic research" after 1945 also took place under different national conditions. Building up on this, in the following, I will analyze the (hindering or promoting) impact of the specialization on the "Slavs" for Hensel's and Herrmann's further careers with regard to the question whether ideological and political "penetration" can be determined for the organization and administration of "Slavic archaeology" in the GDR and the PPR.

\section{2. "At the desk": Hensel and Herrmann as institutional directors and coordinators of "Slavic archaeology"}

After the war, Witold Hensel's career soon gathered further pace, which again, of course, also has to be seen against the background of the postwar situation of the Polish research landscape described above. Among other positions in university administration and the participation in various excavation projects, Hensel was appointed to Chair of the History of Material Culture at the University of Poznań in 1950 and also received a nomination for Chair of Polish Archaeology at the same university in $1951 .{ }^{51}$

As early as in 1946, motivated by his discoveries in the course of excavations in Poznan - as he explained in retrospective ${ }^{52}-$ Hensel published an article in which he explained the need for intensive archaeological research on the origins of the first Polish state and demanded a large-scale excavation campaign, in view of the upcoming millennial anniversary in the $1960 \mathrm{~s}^{53}$ The decision of the communist rulers to support a research project of this size, cost and thematic orientation must be understood in the context of the national legitimation strategy of the communists. ${ }^{54}$ Within the framework of the millennial cam-

${ }^{51}$ Archiwum IAE, 1391/OS-26, Sylwetki naukowe członków PAN, p. 106; Życiorys.

52 Urbanczyk 2008, pp. 153-154.

${ }_{53}$ Hensel 1946. Often the baptism of the first documented Piast ruler, Mieszko I in 966 was (and still is) taken as the symbolic founding date of the first Polish state.

${ }^{54}$ For further information on the funding and the number of employees, methodological assumptions, the role of other researchers such as Aleksander Gieysztor, etc., s. for example Brather 2001a, p. 736; Kurnatowska 2000, pp. 381-412; Młynarska- 
paign, Hensel also participated in archaeological and historical research on the origins of the "Polish state" (which also led to the question of the origin of the "Slavic people(s)"). ${ }^{55}$

As part of the general restructuring of the research landscape in Poland in the 1950s, the tasks and the personnel of the leading committee of the campaign and its subordinate bodies and projects were merged into a new institute, which was part of the Polish Academy of Science: the IHKM. While current research interprets this centralization as a means of establishing a clear hierarchical administration of non-university research, following the Soviet model, to allow for central control and easier implementation of decisions, Hensel retrospectively suggested another explanation. He referred to concepts by Polish researchers (especially by Kazimierz Majewski) dating back to pre-war days to summarize the archaeological and historical research on prehistory and the early Middle Ages under the paradigm of the "history of material culture". ${ }^{56}$ It is quite conceivable that certain aspects from pre-war plans of Polish archaeology and history may have found their way into the shape and structure of the institute, however, it was also due to political premises and compromises that the institute was established. ${ }^{57}$ Therefore, Hensel's account in combination with current research results on the centralization of the Polish research landscape once more sheds light on the connecting and interweaving points, where science and politics cannot be seen as distinguishable spheres. This again shows the value of the biographical approach in connection with consequent contextualisation.

It was due to the foundation of the IHKM that Hensel's workplace moved from Poznań to Warsaw in 1953/54, where he first became the vice director and then the director of the institute..$^{58}$ In 1956, he was also appointed professor for "Slavic archaeology" at the University

-Kaletynowa 2017, pp. 7-12; Moździoch 2009, p. 141; Reichenbach 2009, p. 232; 2016, p. 266; Szczerba 2018, p. 249-252; Urbańczyk 2009, p. 245.

55 Archiwum IAE, 1391/OS-26, Sylwetki naukowe członków PAN, p. 106.

${ }^{56}$ Kurnatowska 2000, p. 385; Lech 1997/1998, p. 79; Reichenbach 2016, p. 267; Stobiecki 2007, p. 109; Urbańczyk 2008, pp. 155-156.

57 Moździoch 2009, p. 140; Urbańczyk 2009, p. 244. This seems possible due to the fact that many researchers with a "pre-war past" took part in the conception process and were among the first (leading) members of the institute.

58 The foundation process of the IHKM and its circumstances are further discussed by Kozłowski 2007, p. 275-276; Lech 2009, pp. 203-209; Szczerba 2018, p. 251. 
of Warsaw. ${ }^{59}$ As director of the IHKM, Hensel was the main person in charge of the millennial research campaign and he could use the practical and organisational experience he had gained before in this field. It was also in the 1950s that the conceptual orientation of the campaign gradually shifted from the focus on Polish national history, closely connected with the traditions of the Polish "Westforschung", to the concentration on social and economic conditions, on the "material culture" in terms of the Polish researchers, as historically relevant factors, which led to a stronger accordance with the principles of the communist understanding of history and historiography, namely with historical materialism. ${ }^{60}$ On the basis of the biographical perspective of this paper, another aspect can be added to this observation: The change of responsibility and institutional binding also strengthened the position of early and prehistorical archaeology in comparison to history, as the examination of past social formations and economic developments lies within the domain of archaeological methodology. This might also be a consequence of the fact that Hensel, someone who strongly promoted the added value of archaeology for "Slavic research", was at the head of the IHKM. ${ }^{61}$

The career path of Joachim Herrmann can also only be understood with regard to the general development of the archaeological and historical research landscape in East Germany, because it is closely connected with restructuring and centralization processes as well. Following the Soviet model, the German Academy of Sciences at Berlin (officially opened in 1946 as the leading institution of non-university research) underwent a broad reform program, the so-called Academy reform, between 1968 and 1972. This reform finally led to a more centralized institution and was also marked by the final renaming to "Academy of Sciences of the GDR" ("Akademie der Wissenschaften der DDR", AdW). ${ }^{62}$ The changes also affected the institutional structure of early

59 Archiwum IAE, 1391/OS-26, Sylwetki naukowe członków PAN, p. 106; Ankieta Personalna.

${ }^{60}$ Reichenbach 2016, p. 273.

${ }_{61}$ Hensel 1950 [1949], pp. 1-4; 1965 [1956], pp. 457-458; 1967, pp. 5, 8, 170. On this aspect, see also Kurnatowska 2000, p. 385-386, 388; Młynarska-Kaletynowa 2017 , pp. 7 ff.

${ }^{62}$ For more information on the reform process see for example Willing 1996, pp. 466, 470-471. 
and prehistorical archaeology, like the "Institute of Early History and Prehistory", Herrmann's workplace so far. When the political authorities and the academy's management level asked for inner-institute proposals concerning the structure of early and prehistorical research within the reformed and centralized academy, Joachim Herrmann was the main initiator who came up with a new concept for a central academical institute, which should include early history and prehistory, "Oriental studies" and Greek and Roman ancient studies. ${ }^{63}$ Herrmann's idea was modified and finally implemented: The ZIAGA at the Academy of Sciences of the GDR was founded and Herrmann became the director of the institute. Therefore, he held a position that came along with a lot of potential influence, which he also used to direct the institutional research towards the principles of historical materialism ${ }^{64}$. On the other hand, with regard to the production of knowledge as a social process and to the active role of scientists in the interrelation with politics and the public, it can be stated that, despite the rigid administrative structures and the ideological requirements from above, there was still room for manoeuvre and various grey areas can be confirmed. This is demonstrated, for example, by the fact that, despite all centralisation efforts and the resulting tense relationship with some representatives of ancient history, Herrmann could (and did) ensure the continuation of long-term research activities such as very specific traditional editing projects of ancient studies under the umbrella of the ZIAGA. ${ }^{65}$ Admittedly, there was no East German equivalent to the millennial campaign in Poland in terms of the extent of participants, funding and public attention. Nevertheless, with Joachim Herrmann as director, a prominent position for "Slavic topics" within the institute and, therefore, within the field of archaeological and prehistorical research in the GDR in general was guaranteed. Due to that, for example, a large-scale "Slavic" project - an extensive study on the history and culture of the "Slavic" tribes until the "feudalistic" "German" eastward

${ }^{63}$ See for example the organigram in Herrmann's conceptions for the new institute as well as other conceptional documents in Archiv der BBAW, NL Herrmann, no. 26.

${ }^{64}$ Willing 1996, p. 471.

65 That is shown by the archival documents that contain the planned long-term projects that Herrmann wanted to continue or establish in the new institute, see Archiv der BBAW, NL Herrmann, no. 24. This aspect is also mentioned by Willing 1996, p. 471. 
expansions - had already been part of Herrmann's initial conception for the institute and received the authorities' approval. ${ }^{66}$

Another example for the prominent status of "Slavic research" connected with Hensel's and Herrmann's institutes and the entanglements with politics that came along with that, were the "International Congresses for Slavic Archaeology", a forum to discuss a wide range of chronological and thematic aspects of the early "Slavs" as well as methodological questions. The congresses brought together the main researchers concerned with the early "Slavs", not only from the countries of the Eastern bloc but of "Western" states as well. ${ }^{67}$ Therefore, these congresses provided various exchange possibilities "undermining" the Iron Curtain. The first congress took place from 14 to 18 September 1965 in Warsaw and was organized by a special planning committee at the IHKM PAN. As president of this committee and of the presidium of the first congress, Witold Hensel took actively part in the preparation and also in the publication of the contributions afterwards. Herrmann, at this time scientific supervisor at the East German prehistorical academical institute, also participated in the event and talked about the social and economic preconditions of the state-forming processes of the "Slavs" west of the Oder. ${ }^{68}$ During this congress, the official foundation of the "Union Internationale d'Archéologie Slave" ("International Union of Slavic Archaeology", UIAS) was initiated by Hensel, who led the association until Karl-Heinz Otto was elected new

${ }^{66}$ See Herrmann's plans in the different versions of the planning documents for the institute in Archiv der BBAW, NL Herrmann, no. 26. The ending date refers to the eastward expansion and settlement movements of "German" groups (previously also - in parts ideologically instrumentalized - called German "Ostkolonisation"/"Colonisation of the East"), which started approximately around the turn of the first millennium. For further information, see for example Piskorski 2006.

${ }^{67}$ This is documented by the collective publications of the two sessions of the congress, see IHKM 1968-1972, and Herrmann 1970-1973, as well as by the archival documents that contain the lists of guests and the conference program, see for example Archiwum IAE 98/Konf./1965, and Archiv der BBAW, NL Herrmann, no. 320. Still, "Eastern" participants were in majority, which can be explained with regard to the easier travel regulations, the political requirements for exchange among the researchers of the Socialist countries and the presence of "Slavic" history in the countries' archaeological and historical research.

${ }^{68}$ Herrmann 1970d, pp. 55-70. 
president of the UIAS in $1967 .{ }^{69}$ The main task of this union was to organize the next congresses at regular intervals and to promote the transnational networking of researchers dealing with "Slavic archaeology". ${ }^{0}$

The second congress took place in East Berlin from 24 to 28 August 1970, mainly initiated and organized by Karl-Heinz Otto and Joachim Herrmann, who held the positions of the first secretary of the national committee and of the leader of the organizational committee. As the director of the ZIAGA, Herrmann also gave a welcoming speech at the beginning of the congress and, because of his position as first secretary of the congress, summed up the main results of the meeting in a closing speech. Witold Hensel also participated in the congress and, among other activities, represented the founding states of the UIAS in a short welcome note. ${ }^{71}$

The archival materials illustrate that the organization of the congresses and further scientific exchange included correspondences with researchers from the West before and after the event. ${ }^{72}$ Therefore, despite the rigid official bloc division, individual possibilities for action and lines of contact and communication within the frame of professional exchange were created and used by the "Slavic archaeologists".

However, the organization of the congresses obviously required cooperation with the leadership of the academy and the political authorities (regarding the provision of financial means, the general consent to the holding of the conferences, etc.) and, thus, compliance with certain demands from above was mandatory: For example, since guests from "socialist" as well as from "capitalist" countries should be invited, special travel authorizations were needed from the state authorities, as shown by a letter of request from Hensel to the foreign ministry. ${ }^{73}$

${ }^{69}$ Točik 1970, p. 39. The foundation of the union was mainly based on the frequent symposia on "Slavic archaeology", which had taken place since 1957, see Brather 2008, pp. 26-27.

${ }^{70}$ Brather 2008, pp. 26-27.

71 Hensel 1970, p. 36.

${ }^{72}$ See for example Herrmann's correspondence in Archiv der BBAW, NL Herrmann, no. 432.

${ }^{73}$ The need for travel permits and the accompanying dependence on decisions from above, which, of course, required a certain level of conformity, affected Hensel and Herrmann and their employees even more when they wanted to travel abroad (especially to countries outside of the Eastern bloc). 
Regarding the congress in East Berlin in 1970, the choice of location also signified the relevance of the East German archaeological and historical research on the "Slavs": "Slavic archaeology" contributed to the integration of the GDR into the community of the socialist states and at least helped to overcome old reservations. This becomes evident when the importance of the second congress for the international reputation of the East German research landscape is highlighted in the laudation for Herrmann being elected corresponding member of the Academy of Sciences in $1972 .{ }^{74}$ Furthermore, in the congratulation letter on Herrmann's $50^{\text {th }}$ birthday in 1982, the president of the academy, Werner Scheler, once again, acknowledged the key role of "Slavic research" for Herrmann's international reputation, which also contributed to the prestige of the ZIAGA and thus of GDR scholarship in general. ${ }^{75}$

\section{3. "In the field": Hensel's and Herrmann's research work}

Despite their administrative tasks as directors of the IHKM and the ZIAGA, Hensel and Herrmann continued field research (excavations) and produced own research results on the prehistoric and early medieval "Slavs", which they presented in their publications. Therefore, the phrase "in the field" is used metaphorically, as this section deals with Hensel's and Herrmann's interpretation of their excavational findings, which, of course, partly took place rather at a desk than "in the field". However, their publications were mainly based on material sources, which required archaeological digging and the examination of artefacts, although both of them now and then took into account written sources as well. Furthermore, the expression "in the field" refers to the fact that this part of the analysis focuses on Hensel's and Herrmann's "practical" research activity (in contrast to their academical education and their administrative work).

${ }^{74}$ Archiv der BBAW: AKL (1969-1991) Pers., no. A 117. The fact that the International Congress for Slavic Archaeology is the only one mentioned in the laudation and that the passage in which it is mentioned has also been included in the summary of the laudation, points to the special status of the conference for the East German archaeology in general and for Herrmann's career in particular.

75 The letter and the draft are available in Archiv der BBAW: AKL (1969-1991) Pers., no. A 117. 
Hensel and Herrmann likewise published an enormous number of scientific studies on the early "Slavs" and, in addition to that, were responsible editors of collective volumes and scientific journals on this topic. ${ }^{76}$ When Hensel and Herrmann explained their research focus on the "Slavic" past in their writings, some aspects, which have already been mentioned when describing their way to the "Slavs", became apparent, again. However, a more in-depth inquiry of their scientific and popular scientific texts significantly adds new results to these observations, as it provides insights into Hensel's and Herrmann's lines of argumentation.

Firstly, it is important to take account of the fact that Hensel and Herrmann had a slightly different geographical focus concerning their object of research. Both referred to the "Western Slavs" (Herrmann sometimes also used the term "Northern Slavs") in a wider geographical frame, but while Hensel concentrated mainly on the "Slavic" groups that had lived on the territory of the Polish state of his days and examined their development with special regard to the formation of the Piast state, Herrmann mostly looked at material (partly also written) evidence of the "Slavs" between the Oder and the Elbe/west of the Oder and the Neisse. ${ }^{77}$ Therefore, tracking "Slavic" traces within the borders of their own states' territories was one of the main purposes of "Slavic archaeology" for Hensel and Herrmann. However, this motivation stemmed from different backgrounds and was closely related to the specific features of the respective "national" history of "Slavic research" and the situation of Poland and East Germany after 1945: As elaborated above, looking for the earliest possible proof of "Slavic" or "Polish" populations on the actual or intended territory of the Polish state already had a vivid tradition in Polish history and archaeology. Since this research goal was still relevant after 1945 with regard to the controversial status of the Western Polish border and its official recognition

${ }^{76}$ Here, they could shape the orientation of these publications, for example through the choice of topics, the selection of contributors and as authors of the opening and closing remarks, see for example their correspondence concerning the preparation of edited volumes such as "Welt der Slawen" / World of the Slavs" (1986), see Herrmann's preparation material including the drafts for the papers (with annotations and comments by the editors) and parts of the correspondence in Archiv der BBAW, NL Herrmann, no. 377 , no. 378 .

${ }^{77}$ See for example Herrmann 1970e, and other publication titles. 
by West Germany still pending, the political context and the climate of the public opinion were reflected in the geographical focus of Hensel's research on the "Slavs", on the location of their alleged common "homeland" and on the analysis of settlement continuities until the formation of the first Polish state. ${ }^{78}$

On the contrary, considering "Slavic" elements as influencing factors for the development of the areas west to the Oder was rather a novelty in German-speaking research: Before 1945, despite a few exceptions, German archaeology and history, especially the "Ostforschung", had rather aimed to highlight the high "Germanic"/"German" cultural level in prehistory and the Middle Ages and mostly denied any lasting historical and cultural "Slavic" achievements - especially in the regions that belonged or were to belong to the German state territory. ${ }^{79}$ Hensel and Herrmann both pointed to this previous pejorative perspective on "Slavic" history and culture as a negative example. While Hensel, especially in the immediate post-war period, demanded intensive Polish "Slavic research" as means of defence and compensation (an attitude that later increasingly softened), Herrmann, instead, derived the need for an "objective" German examination of the "Slavs" from the developments before. ${ }^{80}$

In Herrmann's case, the rejection of the previous German images of the "uncivilized Slavs" went along with the clear distinction from some tendencies in post-war West German archaeological and historical research, which he identified as the continuation of the old "Ostforschung". According to Herrmann, this proved, that East German "Slavic archaeology" had performed a more profound break with the disastrous German past than West German research. ${ }^{81}$ This argu-

78 Examples can be found in Hensel 1960; 1971; 1974, etc.

79 Brather 2001a, p. 732; Lübke 2003, p. 187. For examples of researchers who had shown actual interest in an unbiased approach to the "Slavs" like Rudolf Virchow or Heinrich Felix Schmid, see Brather 2000, p. 149.

${ }^{80}$ See for example Herrmann 1963, p. 810; 1971, p. 8.

${ }^{81}$ Herrmann 1984 [1983], p. 9. Herrmann's statements do have a true core, as in West Germany a few prominent figures of the "Ostforschung" managed to continue their work after 1945 - albeit maybe no longer with the same political and social attention as before. In their interpretations, for example, the concept of the "occident" often replaced the reference to the high "Germanic/German" culture to argue for the supposed Western superiority to the East. This argument was also used for territo- 
ment corresponded to the antifascist self-image of the GDR. Another indication for the influence of the political situation on Herrmann's argumentations can also be found in a publication from 1971, when he mentioned Willy Brandt's "Neue Ostpolitik"/ "New Eastern Policy" of the late 1960s and early 1970s, which he polemically classified as "imperialistic" and linked with the "Ostforschung". ${ }^{82}$ Here, Herrmann's remarks can be interpreted with regard to the initial East German scepticism towards the West German approaches to the Socialist bloc during Brandt's chancellorship, as this was first understood as threatening the loyalty of the other bloc members to the GDR. ${ }^{83} \mathrm{How}-$ ever, in the following years, the increasing political relaxation also enabled new exchange possibilities with Western colleagues. For example, this can be observed in the collective volume "Welt der Slawen" "World of the Slavs" (1986), edited by Joachim Herrmann, which also contained articles by scholars from the West. In this publication, Herrmann referred to more distant and ideologically "harmless" common German points of negative and positive reference such as Leopold von Ranke on the one hand and Johann Gottfried Herder on the other hand. ${ }^{84}$ Here again, the gradual change of the political climate affected the scientific sphere of "Slavic archaeology" - or, in other words, took place also on the level of scientific exchange, which stresses the reciprocal component of processes of political "penetration" between the state and the academic sphere.

Regarding the state of the German-speaking "Slavic research" after the war, Hensel emphasized the positive development of East German "Slavic archaeology" in contrast to the dominating German assumptions on the "Slavs" in the pre-war period rather than talking about West German trends. He also pointed to the shared "Slavic" past as the basis for the common interests and friendship of his country with East Germany and the Soviet Union, which were both very unpopular in Polish society, especially in the first decades after 1945. The fact

rial claims concerning the "old German territories" in the East and to support the West German anticommunism. For further information on the "Ostforschung" before and after 1945 see Mühle 1997, pp. 317-350; 2005; Piskorski 2005, pp. 260-271.

${ }^{82}$ Herrmann 1971, p. 9.

${ }^{83}$ Loose 2008, p. 953.

${ }^{84}$ Herrmann 1986b, p. 9. 
that he combined the positive evaluation of the development of East German archaeology and history with arguing for a close connection between the GDR and the PPR, coincides with the general tendency that Hensel and Herrmann both referred to the prehistoric and early medieval "Slavs" in order to affirm the unity of the socialist bloc ${ }^{85}$ and drew lines of historical continuity from prehistory to their present days. ${ }^{86}$ Especially in the East German case, the reference to the "Slavic heritage" ${ }^{87}$ on the state territory of the GDR was used to create a unifying, somehow common "Slavic" past with the other socialist states and to integrate East Germany in the community of the mostly Slavic-speaking members of the Eastern bloc. Herrmann dated the first arrival of "Slavic" settler groups in the East German territory to the $6^{\text {th }}$ century - earlier than contemporary research does. ${ }^{88}$ In accordance with this classification, Herrmann's description of the further development of the "Slavic" groups in this area also turned out to be timed quite early. Of course, this was also a result of the methods available at that time. Nevertheless, it can be stated that Herrmann did not deeply question or substantiate his early chronological assumptions but welcomed the possibilities of interpretation that came with them rather "uncritically". On this basis, he could argue for a high cultural level and suggest an early economic and social differentiation, which had led to the establishment of "feudalistic" structures at an early stage. ${ }^{89}$ His assumptions

${ }^{85}$ Herrmann 1971, p. 11; Hensel 1965 [1956], p. 460.

${ }^{86}$ In addition to that, the assumption of a "Slavic entity" formed the basis of "Slavic archaeology" (as one can already see from the term). It thus played a central role when it came to legitimizing the existence of this discipline. This might have been one of the reasons why the adherence to the "ethnic paradigm" in archaeology could never be fully overcome in communist East Germany and Poland. For more information on the problems that come along with ethnic interpretations of archaeological sources, see Brather 2000; 2003; 2009; Gąssowski 2003; Pohl 1999; Urbańczyk 2003.

${ }^{87}$ The term "heritage" ("Erbe") can be found, for example, in Herrmann 1971, p. 11, where he connected the GDR with Poland and Czechoslovakia who took over the West Slavic "heritage of cultural-historical achievement" together.

${ }^{88}$ Herrmann 1986a, pp. 33-36, 40; 1970b, pp. 11, 14, 19-21; 1963, p. 810; 1971, pp. 16-17, 22; 1986c, p. 44. For the current state of research see for example Brather 1999, pp. 331, 334; 2001a, p. 741; Mühle 2017, p. 66; Steuer 2001, p. 22.

${ }^{89}$ Herrmann 1970 c, p. $2 ; 1970$ d, p. 50 . On the early datings of "feudalistic" elements in Herrmann's texts and in "Slavic archaeology" in general see Brather 1999, p. 334; 2001a, pp. 741-742; Gringmuth-Dallmer 2001, p. 27. 
were based on the dating of archaeological finds on the territories concerned, which he classified as belonging to different "Slavic" archaeological cultures, for example on pieces of pottery and on the remains of an old hillfort, which he had discovered in Tornow. ${ }^{90}$

Just as Herrmann did, Hensel also aimed to emphasize the high level of prehistorical and medieval "Slavic" culture. In his scientific publications, this occurs especially in connection with the concept of "autochthonous forces". Already in the 1960s, he referred to the discussion about the proportion of "autochthonous" vs. "allochthonous", domestic vs. foreign, factors and their significance for the historical process as one of the most prominent (and still ongoing) controversies in Polish prehistory. By opting for the "autochthonous" theory and for the significance of "internal" conditions and developments over external (for example "Germanic" or "German") cultural or political influences, Hensel explained the assumed high cultural level of the "Slavs" and also their first attempts to the foundation of cities and of statewise structures not as the result of a German "cultural mission" but as "the product of indigenous forces" ("das Produkt einheimischer Kräfte") $)^{91}$. Even though this argumentation had its origin in the Polish archaeological and historical research from the interwar period and even before, ${ }^{92}$ it also enabled the implementation of Marxist-Leninist ideology and serves therefore as an example of "ideological penetration" of "Slavic archaeology" in Poland: By defining "autochthonous elements" as "economic and social forces" (the main driving forces of the historical progress according to the historical-materialist understanding), Hensel combined these two different theoretical backgrounds in his interpretations. ${ }^{93}$

This aspect represents a Polish peculiarity in the East German-Polish comparison, as it demonstrates the specific Polish combination of continuing "bourgeois" narratives with elements of the "new" communist theory and methodology. However, Herrmann argued all the more

${ }^{90}$ See for example Herrmann's interpretations in Herrmann 1966; 1970b; 1970d; 1970e. In the meantime, his dating results has been corrected for example by Brather 1999; Mühle 2017, p. 66; Steuer 2001, p. 22.

${ }_{91}$ Hensel 1967, p. 169; 1960, p. 205; 1965 [1956], p. 459.

92 Stobiecki 2007, p. 110.

${ }^{93}$ Hensel 1965 [1956], p. 456; 1960, p. 205. 
resolutely for the relevance of social and economic factors in history with direct references to communist "standard works", such as quotations from Engels. ${ }^{94}$ In addition to that, communist terms like "ruling classes", "class society", or "class struggle" appeared in Hensel's and Herrmann's studies on the early "Slavs" as well and were therefore applied to pre-modern phenomena, mostly without further problematization..$^{95}$ The fact that the use of these expressions varied depending on the context and intended recipients of the publications, once again points to the initially mentioned nuances of pragmatical and/or idealistic motivations and actions that must be taken into account when analyzing the interrelations between science and politics.

\section{Conclusion}

This paper aimed to provide an insight into the development of "Slavic archaeology" in communist Poland and East Germany, as this thematic field and its protagonists have not comprehensively been researched yet. The main goal was to exemplarily examine the interrelations between science, politics, and ideology to discern if, or respectively to what extent we can assume a certain level of political and ideological "penetration" of "Slavic archaeology". As discussed in the initial theoretical and methodological remarks, the paper intended to approach this question by implementing a biographical perspective on two leading figures of the discipline in the GDR and the PPR. On the example of Joachim Herrmann and Witold Hensel, by analysing the course of their careers, their administrative influences and their research work - always with regard to the political and social context - areas of special entanglements of "Slavic archaeology" with ideology and politics could be determined as well as spaces for action below or against political structures and ideological requirements. Thus, the biographical examples effectively served as "prisms" to illuminate further the broader context of "Slavic archaeology" under the conditions of socialism.

Furthermore, the comparative German-Polish perspective proved to be very fruitful: On the one hand, it helped to draw conclusions

94 Herrmann 1986 [1977], p. 346.

${ }^{95}$ Herrmann 1971, p. 249; 1984 [1983], p. 29; Hensel 1960, p. 34; 1965 [1956], p. 456. 
on more general tendencies of "Slavic research", valid for the GDR and the PPR as well as probably for other states of the Soviet bloc after 1945. On the other hand, this approach enabled to discern unique East German or Polish phenomena in "Slavic archaeology", which could be linked to the respective national histories of "Slavic research" before and to the specific conditions after 1945. These results of the synchronous comparison were complemented by observations in a diachronic perspective, demonstrating that some of the evidence for political and ideological "penetration" was modified over time, in accordance with political and propagandistic changes.

All in all, the chosen biographical-comparative perspective of this paper did not only turn out as an effective approach to a deeper investigation of the history of "Slavic archaeology" under communist rule in East Germany and Poland, but - beyond the examples of Hensel and Herrmann - also proved its further potential for new methodological attempts in the history of science.

This is all the more relevant, as several links for further research can be taken up in addition to this paper. Of course, for a more comprehensive image of "Slavic archaeology" in East Germany and Poland, inquiries on other protagonists as biographical examples and on certain institutions and regional research projects are required. Besides, the comparative perspective on other countries of the Eastern bloc and their "Slavic archaeologies" as well as comparisons between "Eastern" and "Western" narratives and aspects of scientific administration could provide promising insights. With regard to Hensel and Herrmann, a closer look at their active involvement in politics deserves a detailed examination: Herrmann had been a member of the ruling East German "Sozialistische Einheitspartei Deutschlands" ("Socialist Unity Party of Germany", SED) since 1954, while Hensel, as a member of the "Stronnictwo Demokratyczne" ("Alliance of Democrats", $\mathrm{SD}$ ), one of the parties aligned with the socialist forces in Poland, was at times a member of the Sejm, the Polish parliament. Besides, there is further need for research on their careers after the system transformations in the 1980s and 1990s and the collapse of the Eastern bloc, with special regard for example to their standing in the scientific community after the transformation processes or to the question whether they could manage to transfer their potential influences and powers (their different "capitals" with reference to Bourdieu) despite the system 
changes. In this respect, again, parallels and peculiarities between East Germany and Poland and their effects on "Slavic archaeology" are to be discerned.

\section{Acknowledgements}

I express my thanks to the reviewers of the primary version of this article for their helpful comments and supplements and to Mr Filip Klepacki for his attentive proofreading. I would also like to thank Professor Michał Kokowski for his dedicated supervision of the editing and publishing process.

\section{Bibliography}

\section{ARCHIVE SOURCES}

Archiv der Berlin-Brandenburgischen Akademie der Wissenschaften [Joachim Herrmann Papers/Nacblass Joachim Herrmann $=$ NL Herrmann $]$.

Archiv der Berlin-Brandenburgischen Akademie der Wissenschaften [Joachim Herrmann Personal File $/$ Personalakte $=V A-P A]$.

Archiv der Berlin-Brandenburgischen Akademie der Wissenschaften [Documents of the academy administration $/$ Dokumente der Akademieleitung $=A K L]$.

Archiwum Instytut Archeologii i Etnologii PAN AE [Witold Hensel Papers].

Archiwum Instytut Archeologii i Etnologii PAN AE [Documents concerning the First International Congress for Slavic Archaeology/I Miedsynarodony Kongres Archeologii Stowianiskie]

\section{PUBLISHED SOURCES}

Hensel, Witold, 1946: Potrzeba przygotowania wielkiej rocznicy (O niektórych zagadnieniach polskiej protohistorii). Przeglad Wielkopolski 2 (7/8), pp. 193-206.

Hensel, Witold 1950 [1949]: Die Entstehung Polens. Deutsches Büro für Friedensfragen 27, pp. 1-16 [originally published as: Polska na początku dziejów. Przeglad Zachodni 5 (7/8), pp. 134-143].

Hensel, Witold 1960: Die Anfänge des polnischen Staates. Warschau: Polonia-Verlag.

Hensel, Witold 1965 [1956]: Die Slawen im frühen Mittelalter. Ibre materielle Kultur. Berlin: Akademie-Verlag [originally published in several volumes as: Stowianszcryz zna 
wczesnośredniowieczna. Zarys kultury materialnej. Warszawa: Panstwowe Wydawnictwo Naukowe, i. a.].

Hensel, Witold 1967: Anfänge der Städte bei den Ost- und Westslawen. Bautzen: Domowina-Verlag.

Hensel, Witold 1970: Begrüßung für die Gründungsländer der U.I.A.S. [In:] Bericht II. Internationaler Kongreß für Slawische Archäologie. Berlin 24.-28. August 1970. Edited by Joachim Herrmann and Karl-Heinz Otto. $2^{\text {nd }}$ vol. Berlin: Akademie-Verlag, p. 36.

Hensel, Witold 1971: Poczatki państwa polskiego i jego kultury. Wrocław - Warszawa - Kraków: Zakład Narodowy im. Ossolińskich PAN.

Hensel, Witold 1974: Ur- und Frühgeschichte Polens. Berlin: Akademie-Verlag ("Veröffentlichungen des Zentralinstituts für Alte Geschichte und Archäologie der Akademie der Wissenschaften der DDR”, vol. 2).

Instytut Historii Kultury Materialnej PAN 1968-1972: I Miedsynarodowy Kongres Archeologii Stowianskiej. Warszawa 14-18 IX 1965. Wrocław - Warszawa - Kraków: Zakład Narodowy im. Ossolińskich PAN.

Herrmann, Joachim 1963: Rev. Aus Ur- und Frühgeschichte. Hrsg. v. Karl-Heinz Otto namens der Deutschen Historiker-Gesellschaft. Akademie-Verlag, Berlin 1962 [...]. Zeitschrift für Geschichtswissenschaft 11, pp. 809-812.

Herrmann, Joachim (ed.) 1966: Tornow und Vorberg. Ein Beitrag zur Frühgeschichte der Lausitz: Berlin: Akademie-Verlag ("Schriften der Sektion für Vor- und Frühgeschichte", vol. 21).

Herrmann, Joachim 1970a: Die Schichten und Klassen der slawischen Stammesgesellschaft im deutschen Feudalstaat und bei der Ethnogenese des deutschen Volkes - Ein Ausblick: Die Lausitzer Sorben. [In:] Die Slawen in Deutschland. Ein Handbuch. Geschichte und Kultur der slawischen Stämme westlich von Oder und Neiße vom 6. bis 12. Jahrbundert. Edited by Joachim Herrmann. Berlin: Akademie-Verlag, pp. 384-411.

Herrmann, Joachim 1970b: Einwanderung und Wohnsitze der slawischen Stämme in Deutschland. [In:] Die Slawen in Deutschland. Ein Handbuch. Geschichte und Kultur der slawischen Stämme westlich von Oder und Neiße vom 6. bis 12. Jabrhundert. Edited by Joachim Herrmann. Berlin: Akademie-Verlag, pp. 7-44.

Herrmann, Joachim 1970c: Vorbemerkung. [In:] Die Slawen in Deutschland. Ein Handbuch. Geschichte und Kultur der slawischen Stämme westlich von Oder und Neiße vom 6. bis 12. Jahrhundert. Edited by Joachim Herrmann. Berlin: Akademie-Verlag, pp. 1-5.

Herrmann, Joachim 1970d: Wirtschaft und Wirtschaftsentwicklung: Ackerbau. [In:] Die Slawen in Deutschland. Ein Handbuch. Geschichte und Kultur der slawischen Stämme westlich von Oder und Neiße vom 6. bis 12. Jahrhundert. Edited by Joachim Herrmann. Berlin: Akademie-Verlag, pp. 49-56. 
Herrmann, Joachim 1970e: Zu den wirtschaftlichen und gesellschaftlichen Voraussetzungen für die Anfänge der slawischen Staatsbildung westlich der Oder. [In:] I Międzynarodowy Kongres Archeologii Stowiańskiej. Warszawa 14-18 IX 1965. Edited by IHKM PAN. Wrocław - Warszawa - Kraków: Zakład Narodowy im. Ossolińskich PAN, pp. 55-70.

Herrmann, Joachim 1971: Zwischen Hradschin und Vineta. Frühe Kulturen der Westslawen, München: Otto Sagner [originally published in Leipzig - Jena - Berlin: Urania-Verlag].

Herrmann, Joachim 1984 [1983]: Germanen und Slawen in Mitteleuropa. Zur Neugestaltung der ethnischen Verbältnisse zu Beginn des Mittelalters. Vortrag vor der Klasse Gesellschaftswissenschaften II am 14. April 1983. Berlin: Akademie-Verlag ("Sitzungsberichte der Akademie der Wissenschaften der DDR. Gesellschaftswissenschaften”, vol. 3/G).

Herrmann, Joachim 1986a: Die Slawen der Völkerwanderungszeit [In:] Welt der Slawen. Geschichte, Gesellschaft, Kultur. Edited by Joachim Herrmann. Leipzig Jena - Berlin: Urania-Verlag, pp. 19-40.

Herrmann, Joachim 1986b: Einleitung. [In:] Welt der Slawen. Geschichte, Gesellschaft, Kultur. Edited by Joachim Herrmann. Leipzig - Jena - Berlin: Urania-Verlag, pp, 9-10.

Herrmann, Joachim 1986c: Wegbereiter einer neuen Welt - der Welt der Staaten und Völker des europäischen Mittelalters. [In:] Welt der Slawen. Geschichte, Gesellschaft, Kultur. Edited by Joachim Herrmann. Leipzig - Jena - Berlin: UraniaVerlag, pp. 41-56.

Herrmann, Joachim 1986 [1977]: Archäologie als Geschichtswissenschaft. [n:] Wege zur Geschichte. Ausgewählte Beiträge. Edited by Bernhard Tesche. Berlin: Akademie-Verlag, pp., 339-360 [originally published as: Archäologie als Geschichtswissenschaft [In:] Archäologie als Geschichtswissenschaft. Studien und Untersuchungen. Edited by Joachim Herrmann. Berlin: Akademie-Verlag, pp. 9-28].

Herrmann, Joachim; Otto, Karl-Heinz 1970-1973: Berichte über den II. Internationalen Kongreß für Slawische Archäologie. Berlin 24.-28. August 1970, Berlin: Akademie-Verlag.

Kostrzewski, Józef 1970: Z mego ṡycia. Pamiętnik. Wrocław - Warszawa - Kraków: Zakład Narodowy im. Ossolińskich PAN.

Točik, Anton 1970: Bericht des Generalsekretärs der U.I.A.S. [In:] Bericht II. Internationaler Kongreß für Slawische Archäologie. Berlin 24.-28. August 1970. Edited by Joachim Herrmann and Karl-Heinz Otto. $2^{\text {nd }}$ vol. Berlin: Akademie-Verlag, pp. 39-41.

Urbańczyk, Przemysław 2008: Wywiad z Profesorem Witoldem Henslem (roz. przeprowadził Przemysław Urbańczyk). Archeologia Polski 53(1), pp. 147-159. 


\section{STUDIES}

Ash, Mitchell G. 1995: Verordnete Umbrüche - konstruierte Kontinuitäten: Zur Entnazifizierung von Wissenschaftlern und Wissenschaften nach 1945. Zeitschrift für Geschichtswissenschaft 43, pp. 903-923.

Ash, Mitchell G. 2002: Wissenschaft und Politik als Ressourcen füreinander. [In:] Wissenschaften und Wissenschaftspolitik. Bestandsaufnahme zu Formationen, Brüchen und Kontinuitäten im Deutschland des 20. Jahrbunderts. Edited by Rüdiger vom Bruch and Brigitte Kaderas. Stuttgart: Franz Steiner Verlag. ISBN 3-515-08111-9, pp. 32-51.

Behrends, Jan C. 2009: Nation and Empire: Dilemmas of Legitimacy during Stalinism in Poland (1941-1956). Nationalities Papers 37 (4), pp. 443-466.

Berghahn, Volker R. 2008: Structuralism and Biography. Some Concluding Thoughts on the Uncertainties of a Historiographical Genre. [In:] Biography between Structure and Agency. Central European Lives in International Historiography. Edited by Volker Berghahn and Simone Lässig. New York - Oxford: Berghahn Books. ISBN 978-1-84545-518-7 (“Studies in German History”, vol. 9), pp. 234-250.

Bourdieu, Pierre 1986: L'illusion biographique. Actes de la recherche en sciences sociales 62-63, pp. 69-72.

Brather, Sebastian 1999: Einwanderergruppen oder Regionalentwicklung? Die frühen Slawen zwischen Elbe und Oder. Das Altertum 45, pp. 331-346.

Brather, Sebastian 2000: Ethnische Identitäten als Konstrukte der frühgeschichtlichen Archäologie. Germania 78.1, pp. 139-177.

Brather, Sebastian 2001a: Slawenbilder. „Slawische Altertumskunde“ im 19. und 20. Jahrhundert. Archeologické roz̧bledy 53, pp. 717-751.

Brather, Sebastian 2001b: Wilhelm Unverzagt und das Bild der Slawen. [In:] Eine hervorragend nationale Wissenschaft. Deutsche Prähistoriker zwischen 1900 und 1995. Ein Symposium vom 2.-3. Juli 1999 im Rahmen des Sonderforschungsbereiches 541 'Identitäten und Alteritäten. Die Funktion von Alterität für die Konstitution und Konstruktion von Identität' an der Albert-Ludwigs-Universität Freiburg im Breisgau. Edited by Heiko Steuer. Berlin - New York: Walter de Gruyter. ISBN 3-11-017184-8 ("Reallexikon der Germanischen Altertumskunde”, additional vol. 29), pp. 475-504.

Brather, Sebastian 2003: Die Projektion des Nationalstaats in die Frühgeschichte. Ethnische Interpretationen in der Archäologie. [In:] Inventing the Pasts in North Central Europe. The National Perception of Early Medieval History and Archaeology. Edited by Matthias Hardt, Christian Lübke and Dittmar Schorkowitz. Frankfurt/Main: Peter Lang. ISBN 978-3-631-50538-0 (“Gesellschaften und Staaten im Epochenwandel, vol. 9“), pp. 18-42. 
Brather, Sebastian 2008: Archäologie der westlichen Slawen. Siedlung, Wirtschaft und Gesellschaft im früh- und hochmittelalterlichen Ostmitteleuropa. $2^{\text {nd }}$ edition. Berlin - New York: Walter de Gruyter. ISBN 978-3-11-020609-8.

Brather, Sebastian 2009: Ethnische Interpretationen in der europäischen Archäologie. Wissenschaftliche und politische Relevanz. [In:] Politik und Wissenschaft in der prähistorischen Archäologie. Perspektiven aus Sachsen, Böhmen und Schlesien. Edited by Judith Schachtmann, Michael Strobel and Thomas Widera. Göttingen: V\&R unipress. ISBN 978-3-89971-741-9 (“Berichte und Studien”, vol. 56), pp. 31-51.

Brather, Sebastian 2010: Nachruf Prof. Dr. Joachim Herrmann †, 19.12.193225.2.2010. Zeitschrift für Archäologie des Mittelalters 38, pp. 211-214.

Briesewitz, Gernot 2014: Raum und Nation in derpolnischen Westforschung 1918-1948. Wissenschaftsdiskurse, Raumdeutungen und geopolitische Visionen im Kontext der deutschpolnischen Beziehungsgeschichte. Osnabrück: fibre Verlag. ISBN 978-3-94487003-8 ("Einzelveröffentlichungen des Deutschen Historischen Instituts Warschau", vol. 32).

Burda, Tomasz 2004: Reinterpretacja marksizmu przez metodologiczną szkołe poznańską i próba jej zastosowania w archeologii. [In:] Archäologie - Kultur - Ideologie. Archeologia - Kultura - Ideologie. Edited by Bolesław Gediga and Wojciech Piotrowski. Biskupin - Wrocław: ELMA. ISBN 83-915490-3-8, ("Biskupińskie Prace Archeologiczne", vol. 3 / "Prace Komisji Archeologicznej, Wrocław”, vol. 15), pp. 331-346.

Bursche, Aleksander; Taylor, Timothy 1991: A Panorama of Polish Archaeology. Antiquity 65, pp. 583-592.

Coblenz, Werner 2002: Archaeology under Communist Control: The German Democratic Republic, 1945-1990. [In:] Archaeology, Ideology and Society. The German Experience. Edited by Heinrich Härke. $2^{\text {nd }}$ edition. Frankfurt/Main: Peter Lang. ISBN 3-631-38994-9 “"Gesellschaften und Staaten im Epochenwandel”, vol. 7), pp. 308-314.

Curta, Florin 2001a: Pots, Slavs and ,Imagined Communities': Slavic Archaeologies and the History of the Early Slavs. European Journal of Archaeology 4(3), pp. 367-384.

Curta, Florin 2001b: The Making of the Slavs. History and Archaeology of the Lower Danube Region, c. 500-700. Cambridge: Cambridge University Press. ISBN 0-52180202-4 (“Cambridge Studies in Medieval Life and Thought", vol. 4).

De Haan, Binne; Renders, Hans 2014: Introduction. The Challenges of Biography Studies. [In:] Theoretical Discussions of Biography. Approaches from History, Microhistory, and Life Writing. Edited by Binne de Haan and Hans Renders. Revised and augmented edition. Leiden: Brill. ISBN 9789004274705 ("Egodocuments and History Series", vol. 7), pp. 1-8. 
Donat, Peter; Gramsch, Bernhard; Klengel, Horst 2012: Joachim Herrmann (1932-2010). Bericht der Römisch-Germanischen Kommission, vol. 91 (2010), pp. 7-21.

Eckel, Jan 2008: Historiography, Biography, and Experience. The Case of Hans Rothfels. [In:] Biography between Structure and Agency. Central European Lives in International Historiography. Edited by Volker Berghahn and Simone Lässig. New York - Oxford: Berghahn Books. ISBN 978-1-84545-518-7 ("Studies in German History", vol. 9), pp. 85-102.

Frijhoff, Willem 2008: The Improbable Biography. Uncommon Sources, a Moving Identity, a Plural Story? [In:] Biograpby between Structure and Agency. Central European Lives in International Historiography. Edited by Volker Berghahn and Simone Lässig. New York - Oxford: Berghahn Books. ISBN 978-1-84545-518-7 ("Studies in German History", vol. 9), pp. 215-233.

Gassowski, Jerzy 2003: Is Ethnicity Tangible? [In:] Inventing the Pasts in North Central Europe. The National Perception of Early Medieval History and Archaeology. Edited by Matthias Hardt, Christian Lübke and Dittmar Schorkowitz. Frankfurt/ Main: Peter Lang. ISBN 978-3-631-50538-0 (“Gesellschaften und Staaten im Epochenwandel, vol. 9“), pp. 9-17.

Gediga, Bolesław 2004: Poznanie naukowe a społeczne oczekiwania. [In:] Archäologie - Kultur - Ideologie. Archeologia - Kultura - Ideologie. Edited by Bolesław Gediga and Wojciech Piotrowski. Biskupin - Wrocław: ELMA. ISBN 83-915490-3-8, ("Biskupińskie Prace Archeologiczne", vol. 3/"Prace Komisji Archeologicznej, Wrocław”, vol. 15), pp. 213-221.

Goering, D. Timothy 2017: Friedrich Gogarten (1887-1967). Religionsrebell im Jahrbundert der Weltkriege. Berlin: De Gruyter Oldenbourg. ISBN 978-3-11-051730-9 (“Ordnungssysteme”, vol. 51).

Górny, Maciej 2011: 'Die Wabrheit ist auf unserer Seite'. Nation, Marxismus und Geschichte im Ostblock. Köln: Böhlau. ISBN 978-3412207021 ("Europäische Diktaturen und ihre Überwindung“, vol. 16)

Gringmuth-Dallmer, Eike 2001: Die Berliner Akademie der Wissenschaften und die Mittelalterarchäologie in der DDR. Mitteilungen der Arbeitsgemeinschaft für Archäologie des Mittelalters und der Neuzeit 12, pp. 25-31.

Grzechnik, Marta 2017: 'Recovering' Territories: The Use of History in the Integration of the New Polish Western Borderland after World War II. EuropeAsia Studies 69(4), pp. 668-692.

Guth, Stefan 2015: Geschichte als Politik. Der deutsch-polnische Historikerdialog im 20. Jahrbundert. Berlin: De Gruyter Oldenbourg. ISBN 978-3-11-034611-4 (“Ordnungssysteme", vol. 45).

Hackmann, Jörg; Jaworski, Rudolf; Piskorski, Jan M. (eds.) 2002: Deutsche Ostforschung und polnische Westforschung im Spannungsfeld von Wissenschaft und Politik. 
Disziplinen im Vergleich. Osnabrück: fibre Verlag. ISBN 978-3-929759-58-7

("Deutsche Ostforschung und polnische Westerforschung", vol. 1).

Harders, Levke 2014: Legitimizing Biography: Critical Approaches to Biographical Research. Bulletin of the German Historical Institute 55, pp. 49-56.

Harders, Levke; Lipphardt, Veronika 2006: Kollektivbiografie in der Wissenschaftsgeschichte als qualitative und problemorientierte Methode. Traverse. Zeitschrift für Geschichte/Revue d'histoire 13(2), pp. 81-91.

Hardt, Matthias 2015: Ethnogenesen im frühmittelalterlichen Europa. Zum gegenwärtigen Stand der Forschung. [n:] Estnisches Mittelalter. Sprache-GesellschaftKirche. Edited by Kadri-Rutt Hahn, Matthias Thumser and Eberhard Winkler. Berlin: Lit-Verlag. ISBN 978-3-643-13259-8 ("Schriften der Baltischen Historischen Kommission”, vol. 20), pp. 11-24.

Hoppe, Katharina; Quadflieg, Peter M. 2010: Die militärhistorische Biographie: Vom „Bastard der Geschichtswissenschaften“ zur methodischen Chance? (Essay). Newsletter des Arbeitskreises Militärgeschichte e.V. 15(1), pp. 5-10.

Jarausch, Konrad; Middell, Matthias; Sabrow, Martin 1998: Störfall DDR-Geschichtswissenschaft. Problemfelder einer kritischen Historisierung. [In:] Die DDR-Geschichtswissenschaft als Forschungsproblem. Edited by Georg G. Iggers, Konrad Jarausch, Matthias Middell and Martin Sabrow. München: Oldenbourg. ISBN 3-486-64426-2 ("Historische Zeitschrift. Beihefte - Neue Folge", vol. 27), pp. $1-50$.

Kaeser, Marc-Antoine 2006: Mikrohistorie und Wissenschaftsgeschichte. Über die Relevanz der Biographie in der Forschungsgeschichte der Archäologie. Archäologisches Nachrichtenblatt 11(4), pp. 307-313.

Kaeser, Marc-Antoine 2008: Biography as Microhistory. The Relevance of Private Archives for Writing the History of Archaeology. [In:] Archives, Ancestors, Practices. Archaeology in the Light of its History. Edited by Jarl Nordbladh and Nathan Schlanger. New York: Berghahn Books. ISBN 978-1-84545-066-3, pp. 9-20.

Katz, Christiane; Thomes, Paul 2016: Von der Narration zur Methode - Einleitung. [In:] Von der Narration zur Methode. Neue Impulse in der historischen Biographieforschung. Edited by Christiane Katz and Paul Thomes. Aachen: Shaker. ISBN 978-3844048841 ("Aachener Studien zur Wirtschafts-, Sozial- und Technologiegeschichte”, vol. 17), pp. 9-14.

Kershaw, Ian 2008: Biography and the Historian. Opportunities and Constraints. [In:] Biography between Structure and Agency. Central European Lives in International Historiography. Edited by Volker Berghahn and Simone Lässig. New York - Oxford: Berghahn Books. ISBN 978-1-84545-518-7 ("Studies in German History", vol. 9), pp. 27-39. 
Kossack, Georg 1999: Prähistorische Archäologie in Deutschland im Wandel der geistigen und politischen Situation. München: Verlag der Bayerischen Akademie der Wissenschaften. ISBN 3-7696-1605-7 ("Sitzungsberichte der Phil.-Hist. Klasse der Bayerischen Akademie der Wissenschaften”, vol. 4).

Kośnik, Joanna 2007: Lubelski etap działaności Witold Hensla. Archeologia Polski 52(1-2), pp. 219-225.

Kozłowski, Stefan Karol 2007: Imperium atakuje (referat wygłoszony na sesji z okazji 50-lecia IHKM PAN). [In:] Contributions to the Central European Stone Age. Papers dedicated to the late Professor Zbigniew Bagniewski. Edited by Bolesław Ginter, Stefan Karol Kozłowski, Mirosław Masojć and Tomasz Płonka. Wrocław: Instytut Archeologii, Uniwersytet Wrocławski. ISBN 878-83-9210908-2, pp. 273-276.

Krzoska, Markus 2001: Deutsche Ostforschung - polnische Westforschung. Prolegomena zu einem Vergleich. Zeitschrift für Ostmitteleuropa-Forschung 52(3), pp. 398-419.

Kurnatowska, Zofia 2000: Badania nad poczatkami i rozwojem społeczeństwa wczesnopolskiego. [In:] Archeologia i prabistoria polska w ostatnim pótwieczu. Materialy z Konferencji Dorobek polskiej archeologii i prabistorii ostatniego pótwiecza w Puszczykowie koto Poznania (27-30 października 1997 r. Poznań). Edited by Michał Kobusiewicz and Stanisław Kurnatowski. Poznan: PTPN. ISBN 9788370632663 ("Poznańskie towarzystwo przyjaciół nauk. Wydział historii i nauk społecznych. Prace komisji archeologicznej”, vol. 20), pp. 381-412.

Lässig, Simone 2008: Introduction. Biography in Modern History - Modern History in Biography. [In:] Biography between Structure and Agency. Central European Lives in International Historiography. Edited by Volker Berghahn and Simone Lässig. New York - Oxford: Berghahn Books. ISBN 978-1-84545-518-7 ("Studies in German History", vol. 9), pp. 1-26.

Lech, Jacek 1997/1998: Between Captivity and Freedom. Polish Archaeology in the 20th Century. Archaeologia Polona 35/36, pp. 25-222.

Lech, Jacek 2009: O genezie i wzcesnych dziejach Instytutu Historii Kultury Materialnej PAN wraz z uwagami do artykułu Imperium atakuje, pióra Prof. Stefana K. Kozłowskiego (= On the genesis and early development of the Institute of History of Material Culture of the Polish Academy of Sciences with remarks on the paper Imperium atakuje by Professor Stefan K. Kozłowski). Przeglad Archeologiczny 57, pp. 191-214.

Lepore, Jill 2001: Historians Who Love Too Much: Reflections on Microhistory and Biography. The Journal of American History 88(1), pp. 129-144.

Leube, Achim 2010a: Joachim Herrmann. [In:] Prähistorie zwischen Kaiserreich und wiedervereinigtem Deutschland. 100 Jahre Ur- und Frühgeschichte an der Berliner Universität 
Unter den Linden. Bonn: Habelt. ISBN 978-3-7749-3629-4 (“Studien zur Archäologie Europas“, vol. 10), pp. 144-150.

Leube, Achim 2010b: Prähistorie zwischen Kaiserreich und wiedervereinigtem Deutschland. 100 Jahre Ur- und Frühgeschichte an der Berliner Universität Unter den Linden. Bonn: Habelt. ISBN 978-3-7749-3629-4 ("Studien zur Archäologie Europas“, vol. 10).

Levi, Giovanni 1994: On Microhistory. [In:] New Perspectives on Historical Writing. Edited by Peter Burke. $3^{\text {rd }}$ edition. University Park: Pennsylvania State Univ. Press. ISBN 9780271008271, pp. 93-113.

Loriga, Sabina 2014: The Role of the Individual in History. Biographical and Historical Writing in the Nineteenth and the Twentieth Century. [In:] Theoretical Discussions of Biography. Approaches from History, Microbistory, and Life Writing. Edited by Binne de Haan and Hans Renders. Revised and augmented edition. Leiden: Brill. ISBN 9789004274705 ("Egodocuments and History Series", vol. 7), pp. 75-93.

Loose, Ingo 2008: Die Sprachlosigkeit der Ideologie. Polnisch-ostdeutsche geschichtswissenschaftliche Beziehungen 1950-1970. Zeitschrift für Geschichtswissenschaft 56(11), pp. 935-955.

Lübke, Christian 2003: Barbaren, Leibeigene, Kolonisten: Zum Bild der mittelalterlichen Slaven in der deutschen Geschichtswissenschaft. [In:] Inventing the Pasts in North Central Europe. The National Perception of Early Medieval History and Archaeology. Edited by Matthias Hardt, Christian Lübke and Dittmar Schorkowitz. Frankfurt/Main: Peter Lang. ISBN 978-3-631-50538-0 (“Gesellschaften und Staaten im Epochenwandel, vol. 9“), pp. 155-193.

Młynarska-Kaletynowa, Marta 2017: Założenia i pytania badaqcze programu badań milenijnych (Objectives and Research Questions of the Millenial Studies). Przeglad Archeologiczny 65, pp. 7-12.

Moździoch, Sławomir 2009: Wishful digging - Burgwallforschung im Rahmen des polnischen Millenium-Projektes. [In:] Burgwallforschung im akademischen und öffentlichen Diskurs im 20. Jahrhundert. Wissenschaftsgeschichtliche Tagung der Professur für Ur- und Frühgeschichte der Universität Leipzig, 22.-23. Juni 2007. Edited by Susanne Grunwald, Karin Reichenbach and Sabine Rieckhoff. Leipzig: Universität Leipzig, Professur für Ur- und Frühgeschichte. ISBN 3-936394-19-9 ("Leipziger Forschungen zur Ur- und Frühgeschichtlichen Archäologie“, vol. 5), pp. 139-153.

Mühle, Eduard 1997: 'Ostforschung’. Betrachtungen zu einem geschichtswissenschaftlichen Paradigma. Zeitschrift für Ostmitteleuropa-Forschung 46(3), pp. 317-350.

Mühle, Eduard 2017: Die Slawen. München: C.H. Beck. ISBN 978-3406709869 (“C.H. Beck Wissen”, vol. 2872). 
Mühle, Eduard 2020: Die Slawen im Mittelalter zwischen Idee und Wirklichkeit. Wien: Böhlau. ISBN 978-3-412-51898-1.

Nasaw, David 2009: Historians and Biography. Introduction. The American Historical Review 114(3), pp. 573-578.

Neustupný, Evžen 2004: The Ideological Environment of Archaeology. [n:] Archäologie - Kultur - Ideologie. Archeologia - Kultura - Ideologie. Edited by Bolesław Gediga and Wojciech Piotrowski. Biskupin - Wrocław: ELMA. ISBN 83-915490-3-8, ("Biskupińskie Prace Archeologiczne”, vol. 3/"Prace Komisji Archeologicznej, Wrocław”, vol. 15), pp. 223-229.

Nordbladh, Jarl; Schlanger, Nathan 2008: General Introduction. Archaeology in the Light of its Histories. [In:] Archives, Ancestors, Practices. Archaeology in the Light of its History. Edited by Jarl Nordbladh and Nathan Schlanger. New York: Berghahn Books. ISBN 978-1-84545-066-3, pp. 1-5.

Peltonen, Matti 2014: What Is Micro in Microhistory? [In:] Theoretical Discussions of Biography. Approaches from History, Microhistory, and Life Writing. Edited by Binne de Haan and Hans Renders. Revised and augmented edition. Leiden: Brill. ISBN 9789004274705 ("Egodocuments and History Series", vol. 7), pp. 105-118.

Piotrowska, Danuta 1997/98: Biskupin 1933-1996. Archaeology, politics and nationalism. Archaeologia Polona 35-36, pp. 255-285.

Piskorski, Jan M. 2005: Polish „myśl zachodnia“ and German „Ostforschung“. An Attempt at a Comparison. [In:] German Scholars and Ethnic Cleansing, 1919-1945. Edited by Michael Fahlbusch and Ingo Haar. New York - Oxford: Berghahn Books. ISBN 1-57181-435-3, pp. 260-271.

Piskorski, Jan M. 2006: The Medieval Colonization of Central Europe as a Problem of World History and Historiography. German History 22(3), pp. 323-343.

Pohl, Walter 1999: Ethnizität des Frühmittelalters als interdisziplinäres Problem. Das Mittelalter 4, pp. 69-75.

Pyta, Wolfram 2009: Biographisches Arbeiten als Methode. Geschichtswissenschaft. [n:] Handbuch Biographie. Methoden, Traditionen, Theorien. Edited by Christian Klein. Stuttgart: Metzler. ISBN 978-3476022639, pp. 331-338.

Reichenbach, Karin 2009: Die schlesische Burgwallforschung zwischen 1900 und 1970. Forschungskonjunkturen und geschichtspolitische Diskurse. [In:] Politik und Wissenschaft in der prähistorischen Archäologie. Perspektiven aus Sachsen, Böbmen und Schlesien. Edited by Judith Schachtmann, Michael Strobel and Thomas Widera. Göttingen: V\&R unipress. ISBN 978-3-89971-741-9 ("Berichte und Studien", vol. 56), pp. 219-235.

Reichenbach, Karin 2016: Millionen für's Millenium. Finanzierung und Ausstattung der Forschungen zu den Anfängen des polnischen Staates 1949-1953. 
[In:] Die Spur des Geldes in der prähistorischen Archäologie. Mäzene - Förderer - Förderstrukturen. Edited by Susanne Grunwald, Uta Halle, Dirk Mahsarski and Karin Reichenbach. Biefeld: transcript. ISBN 978-3-8376-3113-5 ("Histoire", vol. 81), pp. 259-279.

Renders, Hans 2014: The Limits of Representativeness. Biography, Life Writing, and Microhistory. [n:] Theoretical Discussions of Biography. Approaches from History, Microhistory, and Life Writing. Edited by Binne de Haan and Hans Renders. Revised and augmented edition. Leiden: Brill. ISBN 9789004274705 ("Egodocuments and History Series", vol. 7), pp. 129-138.

Schweiger, Hannes 2009: Biographiewürdigkeit. [In:] Handbuch Biographie. Methoden, Traditionen, Theorien. Edited by Christian Klein. Stuttgart: Metzler. ISBN 978-3476022639, pp. 32-36.

Steuer, Heiko 2001: Deutsche Prähistoriker zwischen 1990 und 1995 - Begründung und Zielsetzung des Arbeitsgesprächs. [In:] Eine hervorragend nationale $W$ issenschaft. Deutsche Prähistoriker zwischen 1900 und 1995. Ein Symposium vom 2.-3. Juli 1999 im Rahmen des Sonderforschungsbereiches 541 „Identitäten und Alteritäten. Die Funktion von Alterität für die Konstitution und Konstruktion von Identität“ an der Albert-Ludwigs-Universität Freiburg im Breisgau, Berlin: de Gruyter. ISBN 3-11-017184-8 ("Reallexikon der Germanischen Altertumskunde. Ergänzungsbd”, vol. 29), pp. 1-54.

Stobiecki, Rafał 2007: Historia i archeologia w pierwszych latach po II wojnie światowej. [n:] Od pradziejów po wspótczesność Archeologiczne wedrówki. Studia dedykowane Pani Profesor Marii Magdalenie Blombergowej. Edited by Marian Głosek and Jerzy Maik. Łódź: ŁTN. ISSN 0065-0986 (“Acta Archaeologica Lodziensia, vol. 53), pp. 106-112.

Strupp, Christoph 2008: A Historian's Life in Biographical Perspective: Johan Huizinga. [In:] Biography between Structure and Agency. Central European Lives in International Historiography. Edited by Volker Berghahn and Simone Lässig. New York - Oxford: Berghahn Books. ISBN 978-1-84545-518-7 ("Studies in German History", vol. 9), pp. 103-118.

Szczerba, Adrianna 2018: From the History of Polish Archaeology. Studies of the Beginning of the Polish State 1948-1966 ("Millenial Program"). Acta Universitatis Lodziensis. Folia Archaeologica 33, pp. 247-254.

Szöllösi-Janze, Margit 2000: Lebens-Geschichte - Wissenschafts-Geschichte. Vom Nutzen der Biographie für Geschichtswissenschaft und Wissenschaftsgeschichte. Berichte zur Wissenschaftsgeschichte 23, pp. 17-35.

Troebst, Stefan 2013: Geschichtspolitik. Politikfeld, Analyserahmen, Streitobjekt. [In:] Geschichtspolitik in Europa seit 1989. Deutschland, Frankreich und Polen im internationalen Vergleich. Edited by Etienne François, Kornelia Kończal, Robert 
Traba and Stefan Troebst. Göttingen: Wallstein. ISBN 978-3-8353-1068-1 ("Moderne europäische Geschichte", vol. 3), pp. 15-36.

Urbańczyk, Przemysław 2003: Do We Need Archaeology of Ethnicity?. [In:] Inventing the Pasts in North Central Europe. The National Perception of Early Medieval History and Archaeology. Edited by Matthias Hardt, Christian Lübke and Dittmar Schorkowitz. Frankfurt/Main: Peter Lang. ISBN 978-3-631-50538-0 (“Gesellschaften und Staaten im Epochenwalde, vol. 9"), pp. 43-49.

Urbańczyk, Przemysław 2009: Medieval Archaeology in Polish Historic-Political Discourse, [In:] Politik und Wissenschaft in der prähistorischen Archäologie. Perspektiven aus Sachsen, Böhmen und Schlesien. Edited by Judith Schachtmann, Michael Strobel and Thomas Widera. Göttingen: V\&R unipress. ISBN 978-3-89971741-9 (“Berichte und Studien”, vol. 56), pp. 237-249.

Veit, Ulrich 2011: Archäologiegeschichte als Wissenschaftsgeschichte: Über Formen und Funktionen historischer Selbstvergewisserung in der Prähistorischen Archäologie. Ethnographisch-Archäologische Zeitschrift 52(1), pp. 34-58.

Wawrzyniak, Joanna 2006: Die Westgebiete in der Ideologie des polnischen Kommunismus. Symbolik und Alltag am Beispiel der Soldatensiedler. [In:] Wiedergewonnene Gebiete. Zur Aneignung von Vergangenheit in den Zwischenräumen Mitteleuropas. Edited by Peter Oliver Loew, Christian Pletzing and Thomas Serrier. Wiesbaden: Harrassowitz. ISBN 978-3447052979 ("Veröffentlichungen des Deutschen Polen-Instituts Darmstadt, vol. 22), pp. 298-319.

Willing, Matthias 1996: Das Ost-Berliner „Zentralinstitut für Alte Geschichte und Archäologie“ im deutschen Vereinigungsprozeß (1989-1992). Geschichte in Wissenschaft und Unterricht 7-8, pp. 466[470]-482.

Wolfrum, Edgar 1999: Geschichtspolitik in der Bundesrepublik Deutschland. Der Weg zur bundesrepublikanischen Erinnerung 1948-1990, Darmstadt: WBG. ISBN 9783534144792.

Zaremba, Marcin 2011: Im nationalen Gewande. Strategien kommunistischer Herrschaftslegitimation in Polen 1944-1980. Osnabrück: fibre. ISBN 978-3-938400-67-8 ("Klio in Polen", vol. 14). 